\title{
BACKGROUND AND REPORT OF THE ATTORNEY GENERAL'S COMMITTEE
}

\section{Stanley N. Barnes $\dagger$}

This prologue discusses broad questions relating to the purpose, organization and general import of the Report of the Attorney General's National Committee To Study the Antitrust Lawes. ${ }^{1}$ The answers to these questions seem indispensable to any evaluation of either the Report or the articles contained in this symposium. First, why was the Committee formed? Second, who were its members? Finally, what general significance does the Report have?

\section{Formation of the Committee}

Some years ago the late Mr. Justice Jackson observed: "If there is one thing that the people are entitled to expect from their law makers, it is rules of law that will enable individuals to tell whether they are married and, if so, to whom." 2 Almost but not quite as important are guides in the antitrust field. The same Justice, commenting less euphemistically on antitrust laws, observed: "A half century of litigation and judicial interpretation has not made the law either understandable or respected." 3

To ease the hazards of uncertainty and increase public respect for antitrust, Attorney General Brownell soon after his appointment set up a National Committee To Study the Antitrust Laws. On March 31, 1955, that group rendered its Report. Now gathered together for the first time in one document is an authoritative viewand occasionally several alternative versions-of most major decisions under the Sherman and Clayton Acts. Thus the Committee sought to aid antitrust enforcement by creating a useful guide to businessmen and their-counsel who seek in good faith to live within the law, and who necessarily must first know what it is. In addition, this guide to what the law is should be of real help to those who consider what the law should be.

$\dagger$ Assistant Attorney General, Antitrust Division, Department of Justice. CoChairman, Attorney General's National Committee To Study the Antitrust Laws.

1. Hereinafter cited as REPORT.

2. Estin v. Estin, 334 U.S. 541, 553 (1948). (Emphasis added.) 256 (1938).

3. Jackson \& Dumbauld, Monopolies and the Courts, 86. U. PA. L. REv. 231, 
Second, the Report sought to suggest broad areas requiring further factual inquiry. ${ }^{4}$ The Committee made no new factual inquiries, for it had no subpoena power, no large research staff, no provision for public hearings and equally important, no sufficient funds. This by no stretch means that the Report was made without regard for the facts of antitrust enforcement. The Committee built upon the accumulated teachings of data already gathered, and, where such data overwhelmingly pointed to one conclusion, the Committee made recommendations based on factual judgments.

However, where members split on the teaching of existing data, the Committee suggested the need for further inquiry. For example, compare the Committee's recommendations on "fair trade" with those on organized labor and regulated industries. In treating "fair trade," almost all members agreed that the economic consequences of legalized resale price maintenance constituted an ". . . unwarranted compromise of the basic tenets of National antitrust policy." 5 In contrast, treating organized labor apart from reported decisions, the Committee could not generalize as to the extent there exist commercial restraints which are not effectively curbed by antitrust law or the Labor-Management Relations Act. Accordingly, the Committee left to Congress the task of determining "the extent" to which such commercial restraints exist unchecked. Similarly, in treating dual conference rate agreements under the Shipping Act, the Committee noted the necessity for a new factual judgment concerning, first, the role of shipping conference activity in our national shipping policy, and second, the necessity of dual rate systems to such conferences.

No scholar or congressional committee will take this Committee's word for those areas where existing data clearly point to one conclusion. Nonetheless this Report may offer leads for antitrust policymakers to areas where further inquiry may be profitable.

\section{Composition of the Committee}

Who were the Committee's members? The Committee's sixtyone members included practicing lawyers, law professors and economists-articulate spokesmen for major points of view on issues of antitrust policy. On the one hand, members included men who had long served the Antitrust Division. Among these were the late Assistant Attorney General Wendell Berge, Kenneth Kimble, A. Stewart

4. At the outset, the Report states its ". . . aim is not to add to the storehouse of statistical data or to survey the economic effects of antitrust applications to specific industries." REPORT at 4.

5. Id. at 154 . 
Kerr, Louis B. Schwartz, Hammond E. Chaffetz and Cyrus V. Anderson. On the other hand, men were also included who counsel all types and sizes of business enterprises. Thus we sought the fairest representation for all possible points of view.

Since the Report's publication, two barbs have been aimed at the Committee's composition. First, debate over the Report's content has occasionally been obscured by charges that, since some members have represented defendants in Department of Justice antitrust actions, their contribution to the Report's analysis and recommendations was inevitably prejudiced. Second, some critics allege that advice by a Committee composed in part of members of the executive branch and, in the main, of private citizens usurps Congress' function of legislation.

The facts, revealed by my staff's search of the Department files, are these: At the time the composition of the Committee was announced, some fifteen of the Committee's sixty-one members were representing defendants in pending proceedings brought by the Antitrust Division. From 1946 to date, only twenty-four of the Committee's sixty-one members represented defendants in cases, pending or closed, brought by the Department of Justice. These figures, of course, tell only a small part of the story. Eight of these twenty-four members, at some time in their careers, served in the Antitrust Division and thirteen of them have enjoyed, or regretted, some experience representing treble damage complainants. Finally, the other two-thirds of the Committee included outstanding law professors, economists and citizens with broad experience in areas other than antitrust litigation.

Criticism of the Committee's membership, based on lawyer members' connections with antitrust defendants misses the mark. A lawyer's occasional representation of one point of view does not produce his complete identification with that view. A client's interest is only one basis for a lawyer's identification. Some others, for example, are social and political affiliations. In appraising antitrust issues, touching as they do basic political and social overtones, it is the complex of all these interests-not solely the experience of client affiliation-which determines any individual's attitudes.

Second, what about the appropriateness of executive-public advisory committees in the antitrust areas? Congressman Patman queried the advisability of a study ". . . of the antitrust laws before the recognized constitutionally established and legally established committees of the Congress" as compared with a process like the Attorney General's Committee. ${ }^{6}$ The two paths of study are not mutually ex-

6. Statement of Congressman Patman in Hearings Before the Special Committee of the Senate To Study Problems of Small Business, 84th Cong., 1st Sess. 514 (1955). 
clusive. Thus, copies of the Report of the Attorney General's Committee were sent to all interested congressional committees. Indeed, four congressional committees have already held hearings on the substance of that Report. It seems clear that the Report may be as useful to the Congress as to the public generally.

At least some members of Congress have recognized the value of the unique role committees composed of non-legislators may play. For example, United States Senator Ives of New York proposed wider use of investigating commissions made up of public citizens as well as legislators. Studies by members of the public at large, he explained, may serve two ". . . crucial functions: First, it is reasonable to expect that the inclusion of men not presently active in the political arena would minimize those excesses which sometimes come with potential political motivation. There would be added further the benefits of the increased perspective which comes with active participation by commission members from outside the halls of Congress. And second, by requiring fewer legislators on the investigating commissions, this proposal would result in a decrease in the work-load for the presently overburdened legislation branch of the Government." 7

Finally, Congressman Patman's query raised, more broadly, the pros and cons of any sort of public advisory committee. At the present time there are some 5,500 advisory committees utilized by the Federal Government. Many may cover areas fit also for congressional inquiry. Nonetheless; few challenge that such public advisory groups may form a crucial link of communication between the Government and those citizens it serves.

\section{SIGNIFICANCE OF THE REPORT}

What general significance does the Report have? Let me answer this question, first, by citing the judgment of others, and, second, by reference to the Report itself.

As the late Wendell Berge, Thurman Arnold's successor as Assistant Attorney General, put it: "I think that the Report . . . represents a signal contribution to antitrust problems. . . . It is my judgment that the Report strongly supports the basic purposes of the antitrust laws. It should receive sympathetic consideration of those members of Congress who have consistently supported the free enterprise system." 8

7. See S. REs. 3775, 81st Cong., 2d Sess. (1950).

8. Hearings Before the Select Committee of the Senate on the Report of the Attorney General's National Committee To Study the Antitrust Laws, 84th Cong., 1st Sess. 61-62 (1955). 
In like tenor, Eugene V. Rostow, Dean of the Yale Law School, said: "The Committee Report is a serious document meriting serious consideration. It should help more than any similar document in recent years to direct attention to genuine problems of policy in the field. . . . It strongly supports the Sherman Act, and the recent vigorous Supreme Court decisions interpreting it. The Report flatly repudiates the plausible argument, backed by several Committees, books and articles in recent years, to exempt so-called 'progressive' monopolies and combinations from the antitrust laws by broadening the rule of reason. It firmly approves the doctrine of per se illegality developed by the courts, and refuses to propose any weakening of the Sherman Act in its application to foreign commerce." 9

To turn to the Report itself, it states at the outset that this Committee without exception ". . . adheres to antitrust fundamentals with full vigor. Although many forces and other Government policies have materially promoted our creative American economy, we believe the antitrust laws remain one of the most important." ${ }^{10}$ The Report later concludes: ". . . a backward look across the 64 years since the Sherman Act reveals on the whole a healthy process of growth through which antitrust fundamentals have gained in strength and effectiveness." 11

These findings can best be valued in the context of recent attacks on much of antitrust. Such forays stemmed from a wide range of sources. On the one hand, David Lillienthal, after a debatable restatement of present antitrust doctrine, concluded: "It is untenable to say that the broad provisions of basic policy in the antitrust laws can bear no other reasonable construction than that now being put upon them, a construction so at variance with the public interest." 12 Similarly, Professor Kenneth Galbraith felt antitrust enforcement might well profit from a ". . . more precise and conscious use of the distinction between original and countervailing power. . . ."13 $\mathrm{He}$ feels there is no justification ", . . for attacking positions of countervailing power which leaves positions of original market power untouched." 14 The 1953 Business Advisory Council Report emphasized: "The statutes, the court decisions and administrative rulings which make up Antitrust Law tend to impede effective competition as often

9. Ibid.

10. REPORT at 2 .

11. $I d$. at 3 .

12. Lilimenthal, Big Business: A New ERA 174 (1953).

13. Galbraith, American Capitalism, The Concept of Countervaining PoWER 145 (1952).

14. Id. at 144 . 
as they protect it from abuse." ${ }^{15}$ Against this background, the Committee's vigorous reassertion of antitrust, I believe, takes on real meaning.

By stating a prevailing and authoritative view of significant antitrust issues, the Report should encourage good faith compliance by American business that seeks to live within the law. For the first time since the passage of the Sherman Act, a group of antitrust experts, representing all shades of opinion, have attempted to set down views on the major issues of antitrust. This comprehensive review and restatement, stating both prevailing and occasional dissenting views, should materially aid those who counsel all sizes of American enterprise.

15. Business Advisory Council, Report to the Secretary of Commerce on EFFECTIVE COMPETTTION (1951). 